\title{
THE CONSERVATION OF ORIGINAL VEGETATION REMNANTS IN THE MIDLANDS, TASMANIA
}

\author{
by R. J. Fensham and J. B. Kirkpatrick
}

(with two tables, three text-figures and an appendix)

FENSHAM, R.J. \& KIRKPATRICK, J.B., 1989 (31:x): The conservation of original vegetation remnants in the Midlands, Tasmania. Pap. Proc. R. Soc. Tasm. 123: 229-246. https://doi.org/10.26749/rstpp.123.229

ISSN 0080-4703. Department of Geography and Environmental Studies, University of Tasmania, GPO Box 252C, Hobart, Australia 7001.

Following 180 years of agricultural settlement, the Midlands area of Tasmania has been drastically transformed and $83 \%$ of the original area of native vegetation has been replaced. By comparing information from two recent intensive floristic surveys with historical botanical records, it was determined that $11.8 \%$ of the higher plant flora has $v$ anished. With current rates of change and land tenure, it is probable that further extinctions will occur in this environment. Grazing was found to increase significantly native species richness on loams and clays, although the same relationship was not evident on sandy soils. The management of grassy remnants should include regular buming and/or grazing as a means of intermittently depleting the grass sward. Many herbaceous exotics are habitat specific, and it is suggested that their passive spread is not an immediate threat to native vegetation on well-drained land. The long-term viability of native vegetation may, however, necessitate the implementation of simple management programs designed to maintain native species diversity and to minimise the spread of the more vigorous woody exotics.

Key Words: grassy vegetation, species richness, grazing, burning, exotics, Tasmanian Midlands, conservation, extinction.

\section{THE CURRENT STATUS OF MIDLANDS VEGETATION}

The Midlands area of Tasmania (fig. 1) was one of the first areas developed for agriculture in Australia and, since the early part of last century, the area has been radically transformed (Kirkpatrick et al. 1988: 17-21). Today, a vast expanse of cultivated ground extends to the base of the surrounding escarpments. Plant communities and species that were restricted to these agriculturally desirable habitats are now confined to scattered refugia that have accidentally avoided destruction. In the period from European settlement to 1985 , native vegetation was reduced to $16.9 \%$ of its original area (fig. 2). With current rates of change, virtually all of the remaining vegetation of the Midlands could be destroyed by forestry and agricultural exploitation; $99.3 \%$ of land is privately owned.

The Midlands form a natural landscape unit, defined by its "mountainous borders, low altitudes, dry climate, broad fertile river valleys and plains. As well as prime agricultural land, it contains dissected dolerite hills and ancient lateritised surfaces. Fensham (1989) identified 14 terrestrial plant communities that are derived from five gross formations, identifiable by their structure or overstorey dominants. These formations are
Eucalyptus amygdalina forest, E. viminalis woodland, E. pauciflora woodland, E. ovata woodland and Poa labillardieri tussock grassland.

Specht (1981) identified the savannah woodlands of temperate southeastern Australia as one of seven major plant formations virtually absent from Australia's reserve network. Surveys of Tasmania's dry forests and grassy ecosystems (Duncan \& Brown 1985, Kirkpatrick et al. 1988) have found all of the major dryland Midlands communities, with the exception of $E$. viminalis woodlands, to be poorly reserved or unreserved.

Most of the Midlands consisted of sparsely wooded plains dominated by E. pauciflora and/or $E$. ovata. These formation survive only in very small areas and are extremely vulnerable to further landscape change. Many roadside remnants continue to be damaged or destroyed by road widening, rerouting and herbicide spraying. In 1985, the Campbell Town cemetery was in excellent native condition and represented one of the last woodland remnants on basalt soils. However, recent "clean up" attempts have excised half of its area into the adjoining paddock, poisoned much of the remainder and disturbed the ground, destroying one of the three known populations of one of Australia's rarest plant species Colobanthus aff. strictus. 


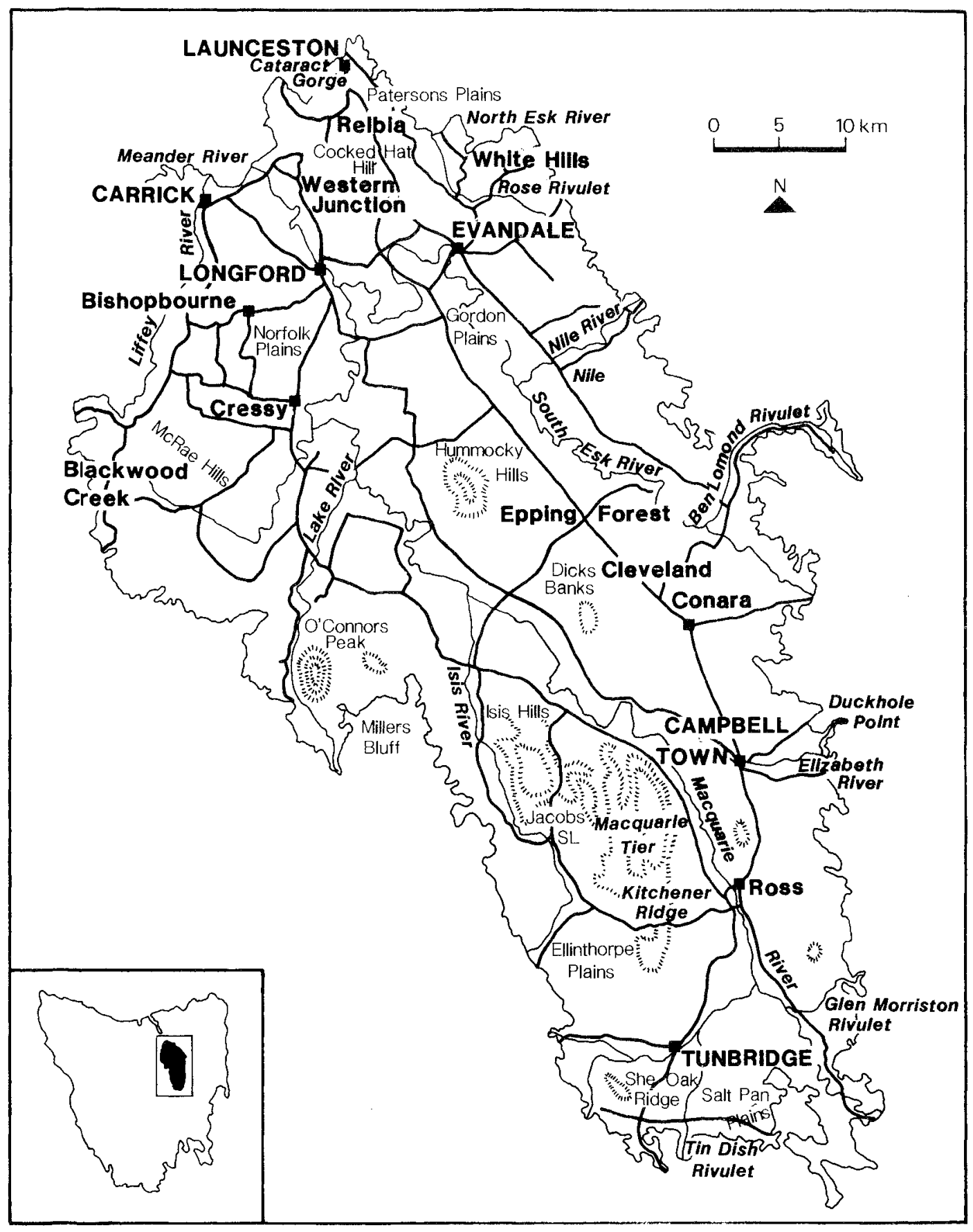

FIG. I-Locality map. 


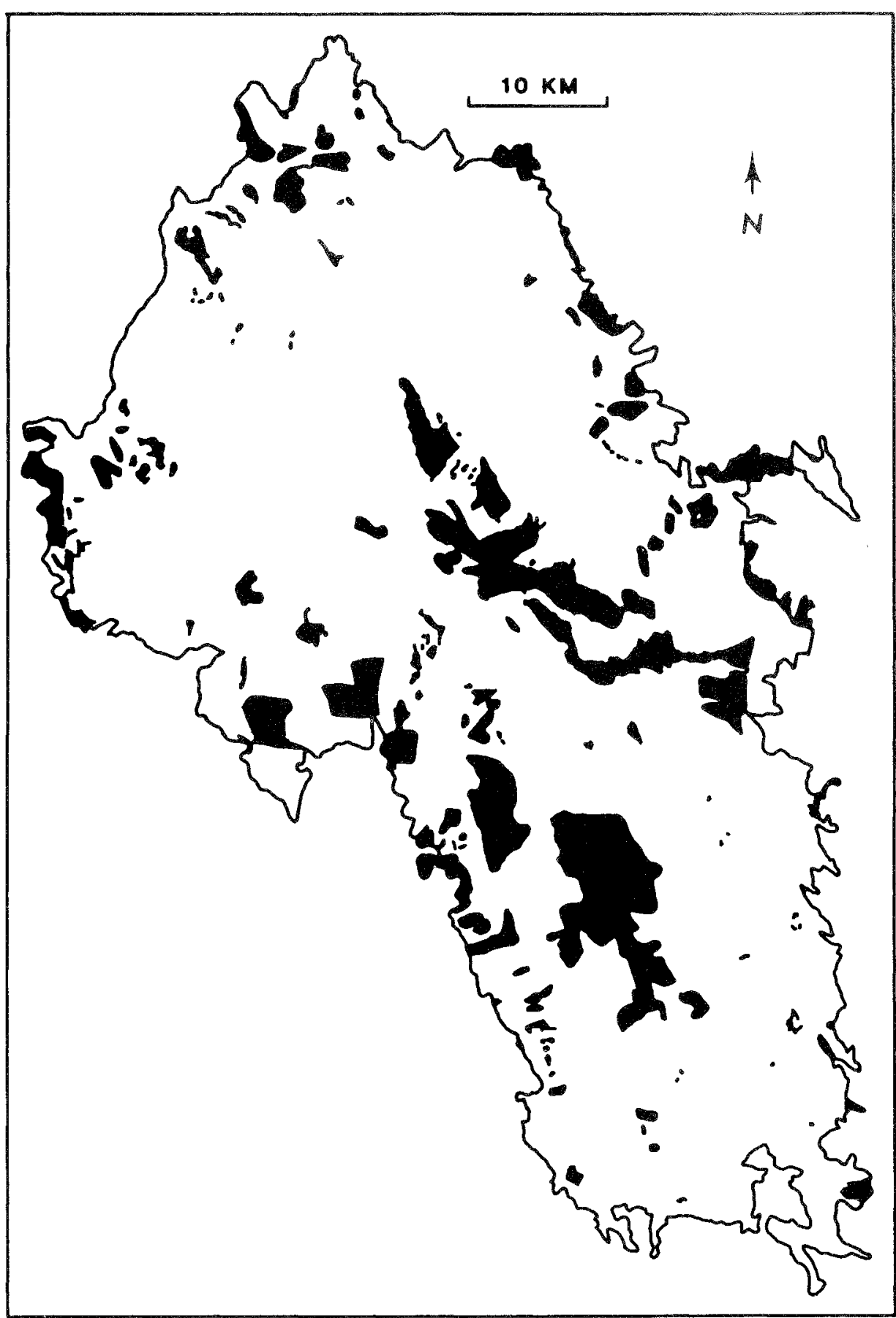

FIG. 2 - Native vegetation remnants, including regenerated clearfell coupes and native pasture with depleted overstoreys; c. 1988. 
Eucalypus amygdalina forest covered large areas of the Midands on poorer soils. However, in recent decades it has been rapidly cleared (fig. 2). The grasslands of the river flats have all been cultivated, with the exception of a small area on the Macquarie River surrounded by steep rocky banks, and a few fragments heavily invaded by exotics. The number of extinct Midlands plant species that were known only from such habitats (appendix) suggests that the full range of these communities has not survived.

The riparian shrub communities are still relatively intact on the edges of the study area at the Macquarie and Elizabeth Rivers and Cataract Gorge. Apart from these peripheral areas riparian communities have virtually disappeared, with the exception of a few small fragments in moderately grazed or rocky situations. The riparian habitat seems particularly susceptible to invasion by woody weeds, especially gorse (Ulex europaeus) and willows (Salix alba), and the native communities have probably been eliminated by grazing.

The aquatic communities still have apparently original complements of native plants as well as many exotic taxa. There is no evidence of the eutrophication that has so seriously affected waterways of intensively cultivated areas in other parts of the world.

Thirty-four per cent of the area under wetlands has been drained, while a further $23 \%$ has been affected by artificial changes of water level (fig. 3). Most of the wetlands have suffered from drainage attempts, although Smiths Lagoon (wetland no.30) has been impounded and Bar Lagoon (wetland no.42) has deepened as a result of increased runoff following clearance and gravel scraping in nearby Verwood Forest (G. Dowling, pers. comm. 1986). of the remaining wetlands, the infrequently inundated margins are susceptible to exotic invasion following disturbance by introduced grazing animals. Many of these communities have depleted native species complements and are dominated by the exotic herb Plantago coronopus.

A search of botanical records and herbarium collections (see appendix for these references) revealed the native species that have been recorded from the Midlands; those not found at these localities in the course of the surveys of Fensham (1989) and Kirkpatrick \& Harwood (1983a,b) are indicated. Where possible, the localities of old records were checked for evidence of the existence of a plant species. However, most old records refer to localities where the chances of finding native species is slight, such as R.C. Gunn's collections from Penquite - now a part of suburban Launceston (Gunn 1842). Some ephemeral species, particularly orchids, may still be present in the Midlands. Herbarium collections marked with the general locality "Launceston" were not included, as they may have occurred outside the study area. Based on this estimate, 59 of the 499 higher native plant species recorded from the Midlands are extinct. Full details of these historical records can be found in Fensham (1985).

Apart from the Orchidaceae, most of the extinct species were associated with riverine habitats - an indication of the degree of native vegetation displacement in these environments. Deyeuxia lawrencii, Goodenia amplexans, Isoetes drummondii, Myriophyllum glomeratum, Prostanthera cuneata and Senecio macrocarpus may now be extinct in Tasmania, although the record for the Goodenia amplexans may refer to a collection in the Melbourne Herbarium marked "Nile Rivulet", which could be a mainland locality. Temporary displacement of aquatic species has been documented for both lentic (Holmes \& Whitton 1977) and lotic water (Millar 1973) and, given that not all waters were thoroughly surveyed, it is probable that the aquatic species Trithuria submersa and Utricularia australis still occur in the Midlands. Chenopodium pumilio and Euphrasia scabra have been germinated recently from soil collected near Ross (L. Gilfedder, pers. comm. 1988), although these annuals have not been observed in the field.

It is unlikely that the full range of plant communities in the Midlands has survived. Dimmock \& Loveday (1953) described a hummocky complex north of Campbell Town as a "complex of low mounds and self-mulching depressions". This is physically comparable to the gilgai complex described by Leeper (1952). The mainland gilgai complexes have been documented as having particular plant associations corresponding to their micro relief features (Williams 1955). The former extent of these formations is unknown. The "hummocky" complexes in the Campbell Town area have nearly all been cultivated and none were located in the study area with native plant cover. 
Conservation of original vegetation remnants in the Midlands, Tasmania

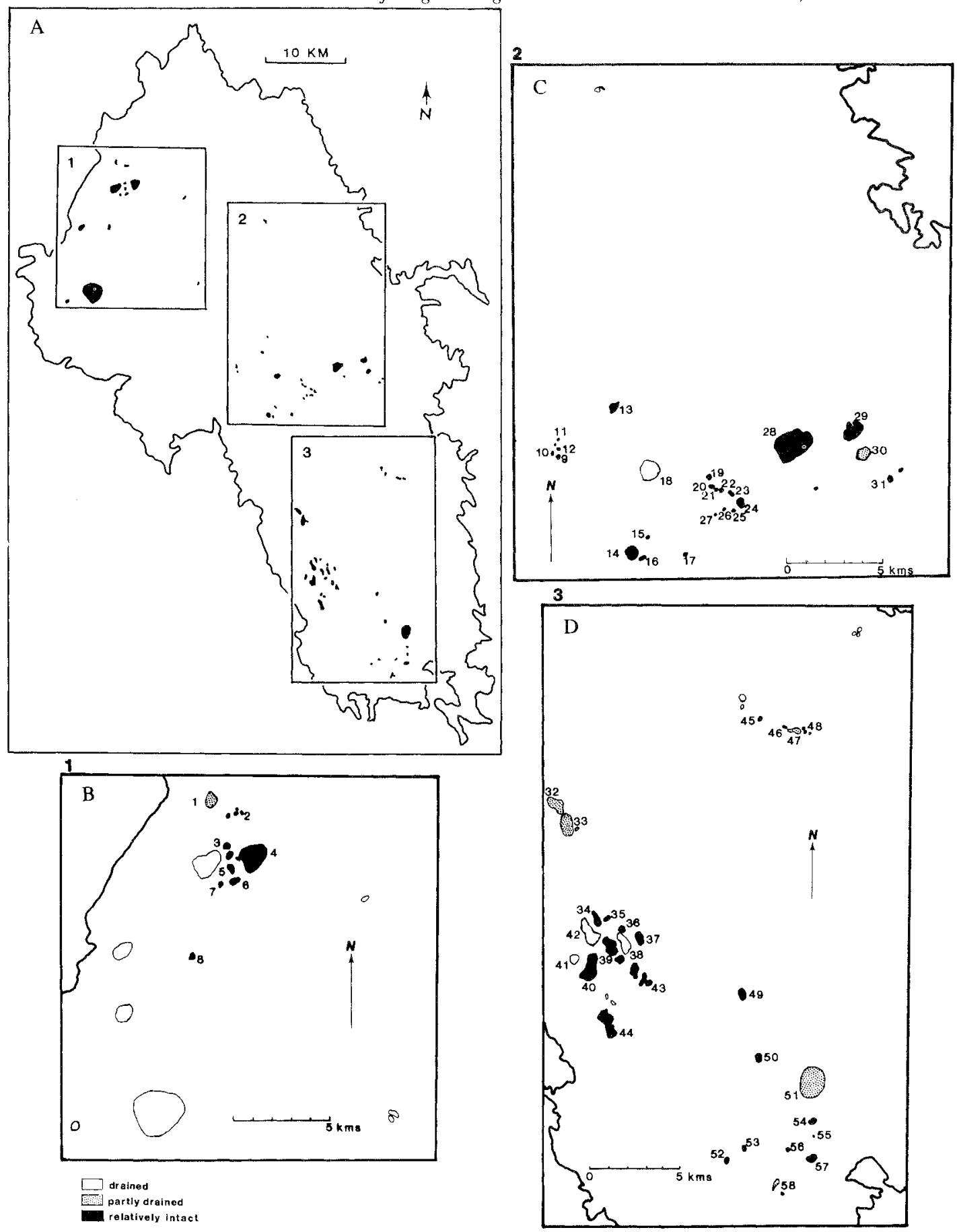

FIG. 3 - (A) Distribution of wetlands in the Midlands showing areas covered by $(B),(C)$ and $(D)$; (B) status of wetlands in area $1 ;(C)$ status of wetlands in area $2 ;(D)$ status of wetlands in area 3. 


\section{STRATEGIES FOR CONSERVATION}

While conservation of major structural formations is desirable, detailed botanical surveys allow for the determination of areas that most efficiently conserve the maximum number of species. This survey discovered several species not previously known from Tasmania, which indicates the importance of survey work in endangered habitats. The appendir shows the Midlands species that are unreserved in Tasmania. The species reservation status was established from herbarium and literature searches and discussion with M. Brown, F. Duncan and L. Gilfedder.

Reservation of areas of Epping Forest would preserve Eucalyptus amygdalina forest and could include the unreserved species Amphibromus macrorhinus, A. neesii, Aphelia gracilis, A. pumilio, Brunonia australis, Caesia parvifolia var. vittata, Caladenia clavigera, Calochilus imberbis, Centipeda minima, Cyperus tenellus, Eragrostis benthamii, Glycine latrobeana, Haloragis aspera, Helipterum australe, $H$. demissum, Hypoxis vaginata, Lomandra nana, Ophioglossum lusitanicum, Pilularia novaehollandiae, Poa hookeri, P. pratermissa, Ptilotus spathulatus, Pultenaea humilis, P. prostrata and Schoenus latelaminatus. Reservation of an appropriate area of grassy native vegetation in the Tunbridge area would preserve Eucalyptus paliciflora woodland and could include the unreserved species Asperula scoparia, Brachyscome rigidula, Calocephalus lacteus, Craspedia sp. "Tunbridge", Cryptandra amara, Danthonia carphoides var. angustior, Dianella longifolia, Isoetopsis graminifolia, Lomandra nana, Poa hookeri, Prasophyllum odoratum, Pterostylis biseta, Scleranthus diander, Stipa scabra, Pultenaea prostrata, Velleia paradoxa, Vittadinia cuneata, V. gracilis, V. muelleri, Wilsonia rotundifolia and the endemic species Stackhousia gunnii. The Tunbridge tip site is on Crown Land and most of it has recently been informally declared a refuge area. The area has been subject to some bulldozing and is probably less desirable for reservation than some of the private paddocks in the area. The case for a reserve in Epping Forest is strengthened by its unusually high concentrations of the restricted endemic marsupial Bettongia gaimardi (Taylor 1988).

The Elizabeth River gorge has already been identified as an area of high priority for plant conservation because of its large healthy populations of the rare endemic species Acacia axillaris (Brown et al. 1983). The area also includes another unreserved endemic Epacris exserta and the unreserved Pimelea pauciflora.

Cataract Gorge in Launceston provides another opportunity of protecting vulnerable species. The presence of the unreserved species Anogramma leptophylla, Doodia media, Helichrysum aff semipapposum, Micrantheum hexandrum and the unreserved endemic species Callitris oblonga and Epacris exserta make this area of public land extremely suitable for reservation.

The wetlands in the study were not identified as high priority areas for plant species conservation by Kirkpatrick \& Harwood (1983b) but since their work the endemic species Ranunculus prasinus has been described (Menadue \& Crowden 1985). This species is only known from Near Lagoon (wetland no.49) and White Lagoon (wetland no.50). Near Lagoon has a population of Bolboschoenus caldwellii and both lagoons have populations of Schoenoplectus validus and extensive herbfields dominated by Wilsonia rotundifolia, all of which are unreserved in the State. A recent analysis of significant wetlands of Tasmania includes Near Lagoon (Kirkpatrick \& Tyler 1988).

Other unreserved species of isolated occurrence on private land or small refuge areas in the Midlands may require protection. While control by the appropriate government body is the most desirable means of protecting valuable natural areas, private ownership is not necessarily incompatible with nature conservation. A private trust fund, for purchasing private land for nature conservation, has been established by the Tasmanian Conservation Trust. However, the owners of valuable Midlands regions have proven reluctant to relinquish even the smallest areas (D. Watts, pers. comm. 1987). The reluctance of governments to purchase, and private owners to part with land suggests alternative means of protection may be necessary. The introduction of legislation such as in South Australia, Victoria and New South Wales, where private landholders receive incentives to protect and preserve natural environments and are required to abide by a suitable management plan (Leigh et al. 1984), would be extremely appropriate for an area like the Midlands. Several landowners have indicated their interest, given some financial incentive, in protecting native vegetation on their land. One small area of land of a sympathetic landowner is inhabited by three rare plant species; it could be simply protected by a relatively short fence. 


\section{VIABILITY AND MANAGEMENT OF SMALL RESERVES IN GRASSY VEGETATION}

\section{Problems}

The viability of small reserves has been the subject of international debate (e.g. Diamond 1975, Simberloff \& Abele 1976, Higgs 1981, Brown \& Hopkins 1983). Whatever the theoretical implications of this discussion, it is certain that the suitability of a particular area as a nature reserve will be idiosyncratic, depending on its significance, the availability of alternatives, the size and shape of the area, the behaviour of the particular vegetation type in the face of surrounding land-use, management problems and the aims of the conservation effort.

One of the most serious problems affecting native vegetation in small reserves in agricultural districts is the edge effect of management practices on adjacent land. The use of herbicides is particularly hazardous; other practices may have less dramatic effects, but nonetheless be deleterious. Drift from fertiliser application has the most serious effect on native vegetation on infertile substrates (Kirkpatrick 1977), particularly where aerial spreading techniques are employed. Thus, a viable reserve on relatively infertile substrates, such as those supporting Eucalyptus amygdalina forest in the Midlands, would need to be larger than one on fertile substrates. However, few remnants on any substrate were observed adjacent to improved pasture. Specht \& Cleland (1961) suggest that buffer zones should be established to absorb the effects of adjacent land-use patterns.

Mechanical ground disturbance and herbicide spraying seriously affect all native vegetation in the Midlands, particularly grassy vegetation on fertile substrates. The prevention of such incursions should ensure the viability of even the smallest remnants, such as roadside and rail verges, for the immediate future, until more adequate reserves are established or plant species relocated to safer habitats.

\section{Species Richness}

The maintenance of species richness in grassy vegetation on fertile soils in southeastern Australia seems to require some mechanism for regularly reducing the biomass of the perennial grasses (Stuwe \& Parsons 1977, Kirkpatrick 1986, Dickinson \& Kirkpatrick 1986). This hypothesis was tested for the Midlands quadrat data set (Fensham 1989) on substrates with a range of fertilities. Quadrats were placed into three broad groups, using the soil textural classes of McDonald et al. (1984): those on dolerite with loams or heavier soils, those on depositional material with light sandy clay loams or lighter soils, and a third intermediate group containing quadrats that could not be defined by these criteria. The Cressy Research Farm and all private property with the exception of two areas not subjected to grazing for several years (as confirmed by the owners) constituted the grazing group. In addition to these two areas the ungrazed group comprised the road and rail reserves, cemeteries, ungrazed Crown Land and city parks. Native species richness was determined for each of the $18010 \times 1 \mathrm{~m}$ quadrats. The percentage frequencies of the individual species were compared between the grazed and ungrazed plots using Student's t-test.

The abundances of grasses, sedges, annual herbs, perennial herbs and shrubs were each compared between grazed and ungrazed sites. Only species with a percentage frequency of more than $10 \%$ in any one comparison were included in the following analysis. Each $20 \%$ difference between the grazed and the ungrazed groups was regarded as a unit. Thus, if a species had a frequency of $75 \%$ in the ungrazed group and $30 \%$ in the grazed group, the abundance of that species in the ungrazed groups was $250 \%$ greater than the grazed group and the species received a score of 12 . Where a species was absent from a group it was given a percentage frequency equivalent to it occurring in one quadrat. The units for all species in each life-form were totalled for both the grazed and the ungrazed treatment. If the importance of grazing did not vary between life-forms, it would be expected that the proportions of units in each treatment for a particular life-form would be equal to the proportion of units in each treatment for the total number of species. The significance of the deviation from the expected value was tested using the chi-squared test.

The comparison between mean native species richness on grazed and ungrazed sites revealed different effects on different soil types and differing life-form groups. It appears that native species richness is increased by grazing on fertile dolerite soils $(\mathrm{t}=5.8, \mathrm{P}<0.001)$ and other clays and loams $(t=2.5, P<0.02)$, but not on infertile sandy soils.

While grazing does not dramatically affect species richness in the grassy heath understoreys on inferiile ground, it can influence community composition. Leucopogon virgatus has been 
virtually excluded from some areas of forest, leaving Hibbertia riparia as the single dominant shrub. When a fence separates an area of forest where grazing has been less intense, Leucopogon virgatus is a codominant member of the understorey.

The percentage frequencies of species of the understorey that were most affected by grazing on fertile soil (all sites except those on sandy soils) are shown in table 1. Small annual herbs and geophytes decline most significantly (chi-squared $=16$,
$\mathrm{P}<0.001$ and chi-squared $=3.3, \mathrm{P}<0.1$ respectively) in the absence of grazing. The larger (Helichrysum apiculatum, Dianella spp.) or twining (Asperula conferta, Convolvulus erubescens) growth-forms may allow some herbaceous species to compete successfully in the ungrazed grass sward.

Grasses showed varying responses, with Deyeuxia quadriseta and most of the shorter grasses such as Agrostis aemula, Danthonia laevis, $D$. tenuior, $D$. carphoides var. angustior and

TABLE 1

Percentage Frequency of Species in Ungrazed and Grazed Treatment Groups* for Quadrats Located on Fertile Ground

\begin{tabular}{|c|c|c|c|c|c|}
\hline & Ungrazed & Grazed & & Ungrazed & Grazed \\
\hline Grasses & & & D. revoluta & 15.9 & 5.9 \\
\hline Dichelachne crinita & 50 & 29.4 & Helichrysum apiculatum & 50 & 17.6 \\
\hline Elymus scabrus & 88.6 & 64.7 & Vittadinia muelleri & 18.2 & 0 \\
\hline Stipa mollis & 18.2 & 8.8 & Acaena echinata & 36.4 & 82.4 \\
\hline S. semibarbata & 36.4 & 17.7 & Arthropodium milleflorum & 6.8 & 14.7 \\
\hline S. stuposa & 84.1 & 61.8 & Dichondra repens & 18.2 & 82.4 \\
\hline Agrostis aemula & 18.2 & 38.2 & Galium gaudichaudii & 4.6 & 14.7 \\
\hline Danthonia carphoides & 36.2 & 56.2 & Glycine latrobeana & 0 & 11.8 \\
\hline D. laevis & 40.9 & 70.6 & Gnaphalium collinum & 25 & 61.8 \\
\hline D. tenuior & 2.3 & 26.5 & Gonocarpus tetragynus & 34.1 & 55.9 \\
\hline Ehrharta stipoides & 43.2 & 94.1 & Hydrocotyle sibthorpioides & 2.3 & 14.7 \\
\hline \multirow[t]{2}{*}{ Pentapogon quadrifidus } & 34.1 & 73.5 & Hypericum gramineum & 18.2 & 67.7 \\
\hline & & & Hypoxis hygrometrica & 2.3 & 11.8 \\
\hline Sedges and rushes & & & Leptorhynchos squamatus & 52.3 & 76.5 \\
\hline Centrolepis aristata & 2.3 & 11.8 & Lomandra longifolia & 27.3 & 64.7 \\
\hline Schoenus apogon & 61.4 & 88.2 & Ptilotus spathulatus & 11.5 & 23 \\
\hline Juncus capitatus & 2.3 & 17.7 & Solenogyne dominii & 13.6 & 38.2 \\
\hline \multirow[t]{2}{*}{ J. subsecundus } & 0 & 20.6 & S. gunnii & 15.9 & 35.3 \\
\hline & & & Veronica calycina & 6.8 & 14.7 \\
\hline Annual herbs & & & $V$. gracilis & 9.1 & 26.5 \\
\hline Senecio quadridentatus & 31.8 & 8.8 & Viola hederacea & 0 & 11.8 \\
\hline Daucus glochidiatus & 11.4 & 38.2 & Wurmbea dioicia & 6.8 & 14.7 \\
\hline Poranthera microphylla & 11.4 & 41.2 & & & \\
\hline Wahlenbergia gracilis & 13.6 & 38.2 & Trees and shrubs & & \\
\hline W. gymnoclada & 4.6 & 20.6 & Bossiaea riparia & 15.9 & 0 \\
\hline W. multicaulis & 4.6 & 44.1 & Eucalyptus pauciflora & 20.5 & 5.9 \\
\hline \multirow[t]{2}{*}{ W. stricta } & 15.9 & 35.3 & Exocarpos cupressiformis & 15.9 & 5.9 \\
\hline & & & Acacia mearnsii & 6.8 & 20.6 \\
\hline Perennial herbs & & & Banksia marginata & 4.6 & 11.8 \\
\hline Acaena ovina & 59.1 & 26.5 & Bursaria spinosa & 40.9 & 73.5 \\
\hline Asperula conferta & 43.2 & 20.6 & Eucalyptus viminalis & 27.3 & 73.5 \\
\hline Caesia vittata & 18.2 & 2.9 & Hibbertia hirsuta & 25 & 61.8 \\
\hline Convolvulus erubescens & 77.3 & 47.1 & Lissanthe strigosa & 36.4 & 70.6 \\
\hline Dianella longifolia & 20.5 & 2.9 & & $\mathrm{n}=44$ & $\mathrm{n}=34$ \\
\hline
\end{tabular}

* Only species occurring in greater than $10 \%$ of either treatment group, where the difference between treatments is more than double or greater than $20 \%$, are included. 
Ehrharta stipoides being favoured by grazing. Themeda triandra declined from $100 \%$ to $82.4 \%$, suggesting a cause for the disappearance of this species on extremely heavily grazed native pastures. All relatively common shrub species of fertile environments were more common in grazed areas, with the exception of Bossiaea riparia, which occurs in paddocks but was not recorded in an ungrazed area.

The maintenance of species richness on the fertile remnants requires some mechanism for intermittently depleting the grass sward. Grazing by marsupial herbivores may be the most suitable method (Kirkpatrick 1986) though, given the animosity towards native animals in agricultural areas, the use of fire may be an appropriate tool for periodically opening the grass canopy. Stuwe \& Parsons (1977) have suggested that exotic species richness is greater in native grassland that is regularly burnt than in the same vegetation type subject to different treatments. However, there is animosity to burning in agricultural areas and, if this practice is not possible, moderate grazing by sheep may be an alternative, though less desirable. Scarlett \& Parsons (1982) have pointed out that the timing and interactions of grazing and firing may be critical to the survival of rare legumes in analogous vegetation in Victoria. Current research being conducted on Tasmanian grassland species may provide information on their survival requirements (L. Gilfedder and J. Whinam, pers. comm. 1979)

\section{EXOTIC SPECIES}

Exotic plant species in the Midlands were recorded from each quadrat during a recent survey of patterns of native vegetation (Fensham 1989); their percentage frequencies, in the classificatory groups established from the native vegetation (Fensham 1989), are shown in table 2 . In some instances different levels of invasion reflect the site selection procedure. Less common environments were sampled with higher exotic complements than would have been tolerated for the more frequent environments. This is the case for the heavily exploited Eucalyptus pauciflora woodlands (groups 8, 9 and 10), where the frequencies of exotics are high. Exotic species abundance may also be a reflection of how recently, or rapidly, they have spread from dispersal centres.
Some exotic species occur in a wide range of Midlands environments. Particularly widespread are the grasses Aira caryophyllea, Briza minor, Holcus lanatus and Vulpia bromoides, and the herbs Centaurium erythraea, Hypochaeris radicata and Trifolium dubium. However, many of the exotic species seem to have strict environmental preferences. For example, Briza maxima prefers well-drained non-claycy substrates and Hypochaeris glabra is widespread but apparently less frequent in the groups of low-lying habitats. By contrast, Juncus articulatus and Lotus tenuis occur in those communities associated with depressions, while Lysimachia nummularia was only seen growing by streams, where it is particularly prolific. Agrostis capillaris, Anthoxanthum odoratum and Filago gallica did not occur in any of the quadrats that comprise groups 8,9 and 10 . These groups are associated with the lowest rainfall zones, and these three species are probably limited by the frequency of drought in the most extreme Midlands environments.

There are virtually no areas in the Midlands without some naturalised exotic species. While the factors that influence most such species are only poorly understood (Weir 1977 cf. Gleadow 1982 , Gleadow \& Ashton 1981, Gleadow \& Row an 1982, Gleadow et al. 1983 for Pittosporum undulatum), the ubiquity of exotic species throughout the Midlands probably reflects the dissected nature of the remnant vegetation and the ready transport of disseminules by a variety of herbivores and machinery.

When the imposed conditions are not detrimental to native vegetation, most exotic species seem to co-exist without causing declines in native species richness (Fensham 1989). This is so for non-woody species in well-drained fertile habitats (Kirkpatrick 1986) and probably also in well-drained infertile substrates in the Midlands, where herbaceous exotic populations appear to be relatively stable. In favourable environments, woody weeds, such as gorse (Ulex europaeus) and blackberries (Rubus fruticosus) may be capable of invading native vegetation where disturbance phenomena are restricted to those that can be assumed for preEuropean conditions. Once established, their ability to form dense thickets excludes native vegetation. The control of these species in the early stages of their invasion is of paramount importance in maintaining the effectiveness of areas of native vegetation for long-term nature conservation. 
TABLE 2

Percentage Frequencies of Exotic Species in the Classificatory Groups* of Fensham (1988)

\begin{tabular}{|c|c|c|c|c|c|c|c|c|c|c|c|c|c|c|}
\hline \multirow[t]{2}{*}{ Species $^{\dagger}$} & \multicolumn{14}{|c|}{ Community } \\
\hline & 1 & 2 & 3 & 4 & 5 & 6 & 7 & 8 & 9 & 10 & 11 & 12 & 13 & 14 \\
\hline Juncus articulatus & - & 50 & 57 & - & - & - & - & - & - & - & - & - & - & - \\
\hline Anthoxanthum odoratum & - & 50 & 57 & - & 7 & 10 & 21 & - & - & - & - & - & - & - \\
\hline Agrostis capillaris & - & - & 14 & - & 13 & - & 29 & - & - & - & 7 & 22 & - & - \\
\hline Cynosurus cristatus & - & - & 14 & - & - & - & - & - & - & - & 11 & - & -- & - \\
\hline Filago gallica & - & - & - & - & 27 & 10 & - & - & - & - & 11 & - & - & - \\
\hline Briza maxima & - & - & - & 57 & 17 & 10 & 14 & - & 83 & 11 & - & - & - & - \\
\hline Aira caryophytlea & 67 & 50 & 71 & 78 & 83 & 86 & 79 & 80 & 83 & 83 & 85 & 67 & - & - \\
\hline Anagallis arvensis & - & - & 43 & 22 & - & 14 & 14 & 10 & - & - & 7 & 22 & - & - \\
\hline Centaurium erythraea & 50 & 100 & 43 & 56 & 47 & 74 & 57 & 25 & 67 & 61 & 56 & 78 & - & - \\
\hline Vulpia bromoides & 67 & 50 & 43 & - & 27 & 52 & 29 & 65 & 50 & 39 & 70 & 78 & - & - \\
\hline Leontodon taraxacoides & - & - & 100 & - & 10 & 45 & - & 35 & - & 11 & 30 & 44 & 67 & 100 \\
\hline Trifolium glomeratum & - & - & 29 & - & - & 10 & - & 75 & - & 11 & 30 & - & - & - \\
\hline Hypochaeris glabra & - & - & - & 33 & 27 & 35 & - & 55 & - & 39 & 33 & - & - & - \\
\hline Romulea rosea & - & - & - & - & - & - & 29 & 10 & - & 11 & - & - & - & - \\
\hline Hypochaeris radicata & 67 & 100 & 43 & 56 & 57 & 69 & 86 & 75 & 50 & 100 & 70 & 78 & 67 & 100 \\
\hline Briza minor & - & 100 & 57 & - & 53 & 76 & 36 & 45 & - & 72 & 74 & 56 & 67 & - \\
\hline Poa annua & - & - & 14 & - & - & - & - & 10 & - & - & - & - & 67 & - \\
\hline Cerastium fontanum & 33 & - & - & - & 13 & - & - & - & 33 & - & 26 & 22 & - & - \\
\hline Cirsium arvense & 67 & - & 14 & - & 13 & 14 & 14 & - & - & 11 & 30 & 56 & 100 & - \\
\hline Trifolium dubium & 33 & 50 & 57 & 22 & 10 & 31 & - & 70 & 83 & 39 & 57 & 78 & 100 & - \\
\hline Rosa rubiginosa & - & - & - & - & - & - & 14 & 15 & - & 11 & 7 & - & - & - \\
\hline Ulex europaeus & - & - & 14 & - & - & - & - & - & - & - & 11 & - & - & - \\
\hline Rubus fruticosus & - & - & 14 & - & - & - & - & - & - & 17 & 11 & - & - & - \\
\hline Trifolium subterraneum & - & - & - & - & - & 7 & - & 20 & - & 17 & 19 & - & - & - \\
\hline Cynosurus echinatus & - & - & 14 & - & - & 21 & - & 50 & - & 17 & 11 & - & -- & - \\
\hline Holcus lanatus & 50 & 100 & 57 & - & 7 & 10 & 21 & - & 50 & 33 & 19 & 78 & 100 & - \\
\hline Taraxacum officinale & - & - & 29 & - & - & - & - & - & - & - & - & 22 & 67 & 100 \\
\hline Agrostis stolonifera & - & 50 & 29 & - & - & - & - & - & - & - & 4 & 33 & - & - \\
\hline Linum trigynum & - & - & - & - & - & - & 22 & - & - & - & 7 & - & - & - \\
\hline Hordeum murinum & - & - & $\ldots$ & - & - & - & - & 10 & - & - & - & - & - & - \\
\hline Dactylis glomerata & - & - & - & - & - & - & - & 10 & - & - & - & - & - & - \\
\hline Geranium dissectum & - & - & - & - & - & - & - & 10 & - & - & - & - & - & - \\
\hline Vicia sativa & - & - & - & - & - & - & - & 10 & - & - & - & - & - & - \\
\hline Erodium cicutarium & - & - & - & - & - & - & - & 20 & - & - & - & - & - & - \\
\hline Lolium perenne & - & - & - & - & - & - & - & 30 & - & - & - & 44 & - & - \\
\hline Plantago lanceolata & - & - & - & - & - & - & - & 35 & - & 22 & 7 & - & - & - \\
\hline Sonchus asper & - & - & - & - & - & - & - & 20 & 33 & - & 7 & - & - & - \\
\hline Plantago coronopus & - & - & - & - & - & - & - & 25 & - & - & 14 & 33 & - & - \\
\hline Rumex acetosella & - & - & - & - & - & - & - & - & 50 & 33 & 19 & - & - & - \\
\hline Bromus hordeaceus & - & - & - & - & - & 17 & - & 90 & 50 & 33 & 30 & 33 & 67 & - \\
\hline Lotus tenuis & - & - & 14 & - & - & - & - & - & - & - & - & 22 & - & 100 \\
\hline Petrorhagia prolifera & - & - & - & - & - & - & - & 50 & - & - & 19 & - & - & - \\
\hline Silene gallica & - & - & - & - & - & - & - & - & - & 11 & - & - & - & - \\
\hline Bromus sterilis & - & - & - & - & - & - & - & 40 & - & 22 & 11 & - & - & - \\
\hline Carduus tenuiflorus & - & - & - & - & - & - & - & 15 & 50 & - & 15 & - & - & - \\
\hline Myosotis discolor & - & - & - & - & - & - & - & - & - & - & 11 & - & - & - \\
\hline Tragopogon porrifolius & - & - & - & - & - & - & - & - & - & - & 7 & - & 67 & - \\
\hline Lysimachia nummularia & - & - & - & - & - & - & - & - & - & - & - & - & - & 100 \\
\hline
\end{tabular}




\section{Notes to Table 2}

* Only species with $>10 \%$ in any group are included.

$\dagger$ Species nomenclature follows Buchanan et al. (1989).

₹ (1) Eucalyptus amygdalina open forest on dolerite hills. (2) E. ovata woodlands on infertile sandy depressions.

(3) Grasslands on moderately fertile sandy depressions. (4) E. amygdalina open forest on flat sandy ground.

(5) E. amygdalina forest on infertile sands. (6) E. amygdalina forest on mixed substrates with moderate rainfall.

(7) E. amygdalina forest on mixed substrates with high rainfall. (8) E. pauciflora woodland on doleritic clay loams.

(9) E. pauciflora woodland on basaltic loams. (10) E. pauciflora woodiand on sand.

(11) E. viminalis woodland on dolerite hills. (12) E. ovata woodlands on clayey depressions.

(13) Grasslands on clayey depressions. (14) Grasslands on riverine flats.

\section{ACKNOWLEDGEMENTS}

We thank Chris Harwood and Steve Harris who conducted much of the field work in the wetlands and Louise Gilfedder and Fiona Coates for a large part of the herbarium searching and for checking a draft of this manuscript. Alex Buchanan, Winifred Curtis, Mary Cameron, Dennis Morris and Tony Orchard drew our attention to important botanical records.

\section{REFERENCES}

Belcher, R.O., 1983: New Australian species of Erecthioid Senecio (Asteraceae). Muelleria 5: $119-122$.

Brown, J.M. \& Hopkins, A.J.M., 1983: The Kwongan (scierophyllous shrublands) of Tuttanning nature reserve, W.A. Aust. J. Ecol. 8: 63-73.

Brown, M.J., KirkPatrick, J.B. \& Moscal, A., 1983: AN ATLAS OF TASMANIA'S ENDEMIC FLORA. Tasmanian Conservation Trust, Hobart.

Buchanan, A.M., McGeary-Brown, A. \& Orchard, A.E., 1989: A census of the vascular plants of Tasmania. Tasm. Herbarium Occ. Pub. No.2.

Diamond, J.M., 1975: The island dilemma: lessons of modern biogeographic studies for the design of nature reserves. Biol. Cons. 7: 129-146.

Dickinson, K.J.M. \& KirkPatrick, J.B., 1986: The impact of grazing in clearfelled, burned and undisturbed eucalypt forest. Vegetatio 66: 133-136.

Dimmock, G.M. \& Loveday, J., 1953: A survey of the basaltic soils near Campbell Town, Tasmania. CSIRO Tech. Mem. 3/53.

Duncan, F. \& Brown, M.J., 1985: Dry sclerophyll vegetation in Tasmania, extent and conservation status of the communities. Wildl. Div. Tech. Rep. 85/1. National Parks and Wildlife Service, Tasmania.
FENSHAM, R.J., 1985: The pre-European vegetation of the Midlands in Tasmania. Unpubl. B.Sc. (Hons) thesis, Geog. Dep., Univ. Tasm.

Fensham, R.J., 1989: The pre-European vegetation of the Midlands, Tasmania: a floristic and historical analysis of vegetation patterns. J. Biogeogr. 16: 29-45.

Gleadow, R.M., 1982: Invasion by Pittosporum undulatum of the forests of central Victoria. II Dispersal, germination and establishment. Aust. $J$. Bot. 30: 185-198.

GleAdow, R.M. \& Ashton, D.H., 1981: Invasion by Pittosporum undulatum of the forests of central Victoria. I - lnvasion patterns and plant morphology. Aust. J. Bot. 29: 705-720.

Gleadow, R.M. \& Rowan, K.S., 1982: Invasion by Pittosporum undulatum of the forest of Central Victoria. III - Effects of temperature and light on growth and drought resistance. Aust. J. Bot. 30: 347-357.

Gleadow, R.M., Rowan, K.S. \& Ashton, D.H., 1983: Invasion by Pittosporum undulatum of the forests of central Victoria. IV - Shade tolerance. Aust. J. Bot. 31: $151-160$.

Gunn, R.C., 1842: Remarks on the indigenous vegetable productions available as food for man. Tasm. J. Nat. Sci. 1: 35-52.

Hewson, H.J., 1982: Brassicaceae. In George, A.S. (Ed.): FLORA OF AUSTRALIA. Vol.8. AGPS, Canberra: 231-357.

HIGGS, A.J., 1981: Island biogeography theory and nature reserve design. J. Biogeogr. 8: 117-124.

Holmes, N.T.H. \& WhitTon, B.A., 1977: The macrophytic vegetation of the River Tees in 1975: observed and predicted changes. Freshw. Biol. 7: 43-60.

KirkPATRICK, J.B., 1977: THE DISAPPEARING HEATH. Tasmanian Conservation Trust, Hobart.

KirkPATRICK, J.B., 1986: The viability of bush in cities - Ten years of change in an urban grassy woodland. Aust. J. Bot. 34: 691-708.

Kirkpatrick, J.B. \& Harwood, C.E., 1983a: Plant communities of Tasmanian wetlands. Aust. J. Bot. 31: $437-451$. 
Kirkpatrick, J.B. \& Harwood, C.E., 1983b: Conservation of Tasmanian macrophytic wetland ve getation. Pap. Proc. R. Soc. Tasm. 117: 5-20.

KirKP iatrick, J.B. \& Tyler, P.A., 1988: Conservation of Tasmanian wetlands. In McComb, A. \& Lake, P.S. (Eds): WETLAND CONSERVATION IN AUSTRALIA. World Wildlife Fund, Sydney.

Kirkpatrick, J.B. Gilfedder, L. \& Fensham, R.J., 1988: CITY PARK AND CEMETERIES: TASMANIA'S REMNANT GRASSLANDS AND GRASSY WOODLANDS. Tasmanian Conservation Trust, Hobart.

LEEPER, G.W., 1952: INTRODUCTION TO SOIL SCIENCE. Melbourne University Press.

LEIGH, J., BODEN, R. \& BRIGGS, J., 1984: EXTINCT AND ENDANGERED PLANTS OF AUSTRALIA. McMillan, Melbourne.

McDonald, R.C., Isbell, R.F., Speight, J.G., Walker, J. \& HOPKINS, M.S., 1984: AUSTRALIAN SOIL AND LAND SURVEY. FIELD BOOK. Inkata Press, Adelaide.

Menadue, Y. \& Crowden, R.K., 1985: Three new species of Ranunculus (Ranunculaceae) from Tasmania. Brunonia 8: 373-380.

Milla R, J.B., 1973: Vegetation changes in shallow marsh wetlands under improving moisture regime. Can.J. Bot. 51: 1443-1457.

RODWAY, L., 1903: THE TASMANIAN FLORA. Government Printer, Hobart.

Scarlett, N.H. \& Parsons, R.F., 1982: Rare plants of the Victorian plains. In Groves, R.H. \& Ride, W.D.L. (Eds): SPECIES AT RISK: RESEARCH IN AUSTRALIA. Australian Academy of Science, Canberra.
SimberlofF, D.S. \& Abele, L.G., 1976: Island biogeography theory and conservation practice. Science 191: 285-286.

SPECHT, R.L., 1981: Conservation of vegetation types. In Groves, R.H. (Ed.): AUSTRALIAN VEGETATION. Cambridge University Press.

Specht, R.L. \& Cleland, J.B., 1961: Flora conservation in South Australia. I - The preservation of plant formations and associations recorded in South Australia. Trans. R. Soc. S. Aust. 85: 177-197.

SPICER, W.W., 1878: A HANDBOOK OF THE PLANTS OF TASMANIA. J. Walch \& Sons, Hobart.

STUWE, J. \& PARsONS, R.F., 1977: Themeda australis grasslands on the Basalt Plains, Victoria: floristics and management effects. Aust. J. Ecol. 2: 467-476.

TAYLOR, R.J., 1988: Ecology and conservation of the Tasmanian bettong (Bettongia gaimardi). Unpubl. rep. Australian National Parks and Wildlife Service.

WeIR, J.S., 1977: Exotics: Past, present and future. In Anderson D. (Ed.): EXOTIC SPECIES IN AUSTRALIA - THEIR ESTABLISHMENT AND SUCCESS. Proc. Ecol. Soc. Aust. 10: 4-14.

Williams, O.B., 1955: Studies in the ecology of the Riverine Plain. 1 - The gilgai microrelief and associated flora. Aust. J. Bot. 3: 99-112.

(accepted I8 August I989) 


\section{APPENDIX}

List of Known Midlands Higher Plant Species, showing those presumed to be extinct in the region (*), those unreserved in Tasmania $(\dagger)$

Numbers refer to references confirming the previous existence of an extinct species.
(1) Spicer (1878)
(3) Hewson (1982)
(2) Rodway (1903)
(5) Leigh et al. (1984)
(4) Belcher (1983)
(7) Queen Victoria Museum, Herbarium
(6) Tasmanian Herbarium

(9) D. Morris, pers. comm. 1986 (specimen held at Kew Herbarium, London) (10) A. Buchanan, pers. comm. 1989 (specimen held at N.S.W. Herbarium)

Nomenclature follows Buchanan et al. 1989.

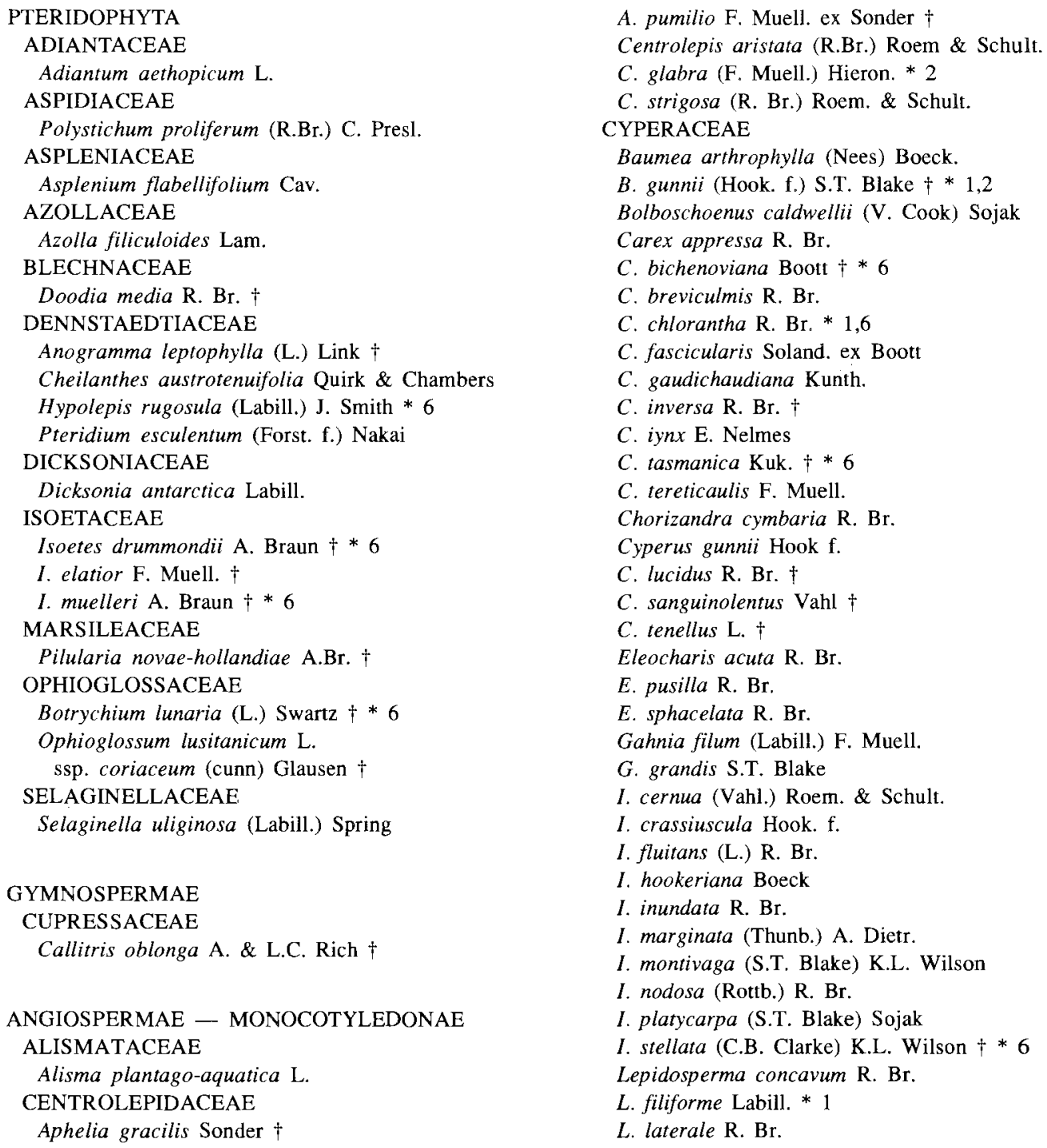




\author{
L. lineare $\mathrm{R} . \mathrm{Br}$. \\ L. longitudinale Labill. \\ Schoenoplectus pungens (Vahl) Palla \\ $S$. validus (Vahl) A. \& D. Love $\dagger$ \\ Schoenis apogon Roem. \& Schult. \\ S. fluituns $\mathbf{L}$. \\ S. la telaminatus Kuekenth. $\dagger$ \\ S. maschalinus Roem. \& Schult. \\ $S$, niters (R.Br.) Poir. \\ S. tesquorum J.M. Black \\ HYDA TELLACEAE
}

Trithuria submersa Hook. f. †*2,6

HYDROCHARITACEAE

Vallisneria gigantea Graebner

HYPOXIDACEAE

Hypoxis hygrometrica Labill.

$H$. vaginata Schldl. $\dagger$

IRIDACEAE

Diplarrena moraea Labill.

\section{JUNCACEAE}

Juncus amabilis Edgar $\dagger$

$J$. australis Hook. $\mathrm{f}$.

$J$. bufonius $\mathbf{L}$.

$J$. capitatus Weig.

$J$. filicaulis Buch.

$J$. holoschoenus $\mathrm{R}$. Br.

$J$. kraussii Hochst.

$J$. pallidus $\mathrm{R}$. Br.

J. pauciflorus $\mathrm{R}$. Br.

J. planifolius $\mathrm{R}$. Br.

$J$. procerus E. Mey.

$J$. sarophorus L.A.S. Johnson

$J$. subsecundus N.A. Wakefield

Luzula spp.

JUNCAGINACEAE

Triglochin procera $\mathrm{R}$. Br.

T. striata Ruiz. \& Pav.

\section{LEMNACEAE}

Lemna disperma Hegelm

L. trisulca L.

Wolffia australiana (Benth.) Hartog and Plas. $\dagger$

\section{LILIACEAE}

Arthropodium milleflorum (DC.) Macbride

A. minus $\mathrm{R}$. Br.

Bulbine glauca (Raf.) E.M. Watson

Burchardia umbellata $\mathrm{R}$. Br.

Caesia parviflora $\mathrm{R}$. $\mathrm{Br}$.

var. parviflora

var. vittata (R. Br.) R. Henderson $\dagger$

Chaemaescilla corymbosa (R. Br.) F. Muell. ex Benth.

Dianella longifolia $\mathrm{R} . \mathrm{Br} . \dagger$

D. tasmanica Hook. $\mathrm{f}$.

Dichopogon strictus (R. Br.) Baker

Thysanotus patersonii $\mathrm{R}$. Br.
Tricoryne elatior $\mathrm{R}$. Br.

Wurmbea dioica (R. Br.) F. Muell.

ORCHIDACEAE

Caladenia catenata (Sm.) Druce

C. caudata W.H. Nicholls

C. clavigera A. Cunn ex Lindley +

C. cucullata FitzG.

C. pattersonii $\mathrm{R}$. Br.

Calochilus imberbis R.S. Rogers †

C. gunnii Lindley * 6

C. reflexa (Labill.) Druce * 6

Corybas incurvus D. Jones \& M. Clements $\dagger * 6$

Dipodium punctatum (Smith) R. Br.

Diurus maculata Smith

D. sulphurea R. Br. *6

Eriochilus cucullatus (Labill.) Reichb. f.

Glossodia major R. Br.

Microtis unifolia (Forst. f.) Reichb. f.

Prasophyllum odoratum R.S. Rogers $\nmid * 6$

Pterosylis biseta J.A. Blackmore \& Clemesha $†$

P. curta R. Br.

P. furcata Lindley * 6

P. mutica $\mathrm{R}$. Br. ${ }^{*} 6$

$P$. pedunculata $\mathrm{R}$. Br.

P. rufa $\mathrm{R} . \mathrm{Br}$.

Spiranthes sinensis (Pers.) Ames * 1

Thelymitra aristata Lindley * 6

T. carnea $\mathrm{R} . \mathrm{Br}$.

T. megcalyptra R.D. FitzG.

T. pauciflora $\mathrm{R} . \mathrm{Br}$.

\section{POACEAE}

Agrostis aemula $\mathrm{R}$. Br.

A. avenacea J.F. Gmel.

A. billardieri $\mathrm{R}$. $\mathrm{Br}$.

A. venusta Trin.

Amphibromus archeri (J.D. Hook.) P.F. Morris

A. macrorhinus S.W.L. Jacobs \& L. Lapinpuro $\dagger$

A. neesii Steud. $\dagger$

A. recurvatus Swallen

A. sinuatus S.W.L. Jacobs \& L. Lapinpuro $\dagger$

Danthonia caespitosa Gaudich.

D. carphoides F. Muell. ex Benth.

var. angustior Vickery $\dagger$

D. dimidiata Vickery

D. laevis J.W. Vickery

D. penicillata (Labill.) P. Beauv.

D. pilosa $\mathrm{R}$. Br.

D. popinensis D.I. Morris †

D. procera Vickery $\dagger$

D. racemosa $\mathrm{R}$. Br.

D. semiannularis (Labill.) $\mathrm{R}$. $\mathrm{Br}$.

D. setacea $\mathrm{R}$. Br.

D. tenuior (Steudel) Conert

Deyeuxia lawrencii Vickery $\dagger * 9$

D. quadriseta Benth. 
Dichelachne crinita Hook.

D. rara (R. Br.) Vickery

Distichlis distichophylla (Labill.) Fassett

Echinopogon ovatus (G. Foster) P. Beauv.

Elymus scabrus (Labill.) A. Love

Eragrostis molybdea Vic. $\dagger$

Ehrharta acuminata (R. Br.) Sprengel * 1

E. distichophylla Labill.

E. stipoides Labill.

Festuca plebeia $\mathrm{R}$. Br.

F. hookeriana F. Muell. ex J.D. Hook. ${ }^{*} 1$

Glyceria australis C.E. Hubb

Hemarthria uncinata $\mathrm{R}, \mathrm{Br}$.

Pentapogon quadrifidus Baill.

Phragmites australis (Cav.) Trin. ex Steudel

Poa hookeri Vick. †

$P$. labillardieri Steud.

$P$. mollis Vick. $\dagger$

$P$. pratermissa D.I. Morris $\dagger$

$P$. rodwayi Vickery

$P$. sieberiana Spreng.

Puccinellia stricta (Hook. f.) C. Blom

Stipa bigeniculata Hughes

S. mollis $\mathrm{R}$. Br.

S. nodosa S.T. Blake

S. pubinodis Trinius \& Rupecht

S. rudis Sprengel

ssp. australis J. Everett \& S. Jacobs

S. scabra Lindley $\dagger$

S. semibarbata R. Br.

S. stuposa D.K. Hughes

Themeda triandra Forsskal

Zoysia macrantha Desv.

POTAMOGETONACEAE

Potamogeton australiensis A. Bennett

P. crispus $\mathbf{L}$.

$P$. ochreatus Raoul $\dagger$

$P$. pectinatus $\mathrm{L} . \dagger$

$P$. perfoliatus $\mathrm{L}$ 。 $\dagger$

P. tricarinatus F. Muell. \& A. Bennett ex A. Bennett

\section{RESTIONACEAE}

Leptocarpus brownii Hook. f.

Lepyrodia muelleri Benth.

RUPPIACEAE

Ruppia maritima $\mathrm{L}$.

\section{TYPHACEAE}

Typha domingensis Pers.

T. latifolia $\mathrm{L}$.

\section{XANTHORRHOEACEAE}

Lomandra nana (A. Lee) A. Lee +

L. longifolia Labill.

\section{ZANNICHELLIACEAE}

Lepilaena cylindrocarpa (Kornicke) Benth.

L. preissii (Lehm.) F. Muell. $\dagger * 2$

\author{
ANGIOSPERMAE - DICOTYLEDONS \\ AMARANTHACEAE \\ Alternanthera denticulata $\mathrm{R}$. Br. $\dagger * 7$ \\ Ptilotus spathulatus (R. Br.) Poir. $\dagger$ \\ APIACEAE \\ Apium prostratum Labill, ex Vent. \\ Centella cordifolia (Hook. f. ) Nannfeldt \\ Daucus glochidiatus (Labill.) Fisch. et al. \\ Eryngium vesiculosum Labill. \\ Hydrocotyle callicarpa Bunge \\ H. muscosa R. Br. \\ $H$. sibthorpioides Lamk. \\ Lilaeopsis polyantha (Gand.) H. Eichler \\ Trachymene humilis (Hook. f.) Benth. $\dagger$ \\ ASTERACEAE \\ Angianthus preissianus (Steetz) Benth. \\ Bedfordia salicina (Labill.) DC. \\ Brachyscome aculeata (Labill.) Less. \\ B. angustifolia A. Cunn. ex DC. ${ }^{*} 6$ \\ $B$. cardiocarpa F. Muell. ex Benth. \\ B. decipiens Hook. f. * 6 \\ $B$. radicans Steetz in Lehm. $\dagger$ \\ B. rigidula (DC.) G.L. Davis $\dagger$ \\ B. spathulata Gaud. \\ Calocephalus lacteus Lessing $\dagger$ \\ Centipeda minima (L.) A. Br. \& Aschers. \\ Cotula australis (Sieber ex Spreng.) Hook. f. * 6 \\ C. coronopifolia $\mathrm{L}$. \\ C. reptans (Benth.) Benth. \\ Craspedia glauca (Labill.) Spreng. \\ Craspedia sp. "Tunbridge" $\dagger$ \\ Cymbonotus lawsonianus Gaudich. \\ Gnaphalium collinum Labill. \\ $G$. involucratum Forst. f. \\ G. purpureum L. \\ Helichrysum apiculatum (Labill.) D. Don. \\ H. bicolor Lindl. \\ $H$. dendroideum N.A. Wakefield \\ H. scorpioides Labill. \\ $H$. semipapposum (Labill.) DC. \\ $H$. aff. semipapposum "Launceston" $\dagger$ \\ H. thyrsoideum (DC) P. Morris \& J.H. Willis * 6 \\ Helipterum albicans (A. Gunn) DC. \\ var. incanum (Hook.) P.G. Wilson $\dagger$ \\ $H$. anthemioides (Sieber ex Spreng.) DC. $\dagger * 6$ \\ $H$. australe (A. Gray) Druce $\dagger$ \\ H. demissum (A. Gray) Druce $\dagger$ \\ Isoetopsis graminifolia Trucz. $\dagger$ \\ Lagenifera huegelii Benth. * 9 \\ L. stipitata (Labill.) Druce \\ Leptorhynchos elongatus DC. $*+2,6$ \\ L. linearis Lessing \\ L. squamatus (Labill.) Lessing \\ Microseris lanceolata (Walp.) Schultz-Bip. \\ Millotia tenuifolia Cass. =
}


Olearia argophylla (Labill.) Benth.

o. ciliata (Benth.) F. Muell. ex Benth. * 1

o. floribunda (Hook. f.) Benth.

O. ramulosa (Labill.) Benth.

o. stellulata (Labill.) DC.

O. viscosa (Labill.) Benth.

Podolepis jaceoides (Sims) Voss

Pseudognaphalium luteo-album (L.) Hilliard \& B.L.

Burtt.

Senecio glomeratus Desf. ex Poir.

S. hispidulus A. Rich.

S. macrocarpus Belcher $\dagger * 4$

S. quadridentatus Labill.

Solenogyne dominii L. Adams

$S$. gunnii (Hook. f.) Carbrera

Vittadinia cuneata DC. $\dagger$

V. gracilis (Hook. f.) N. Burb. $\dagger$

V. muelleri $\mathrm{N}$. Burb. $\dagger$

\section{BORAGINACEAE}

Cynoglossum australe $\mathrm{R}$. $\mathrm{Br}$.

C. suaveolens $\mathrm{R}$. Br.

Myosotis australis $\mathrm{R} . \mathrm{Br}$.

BRA SSICACEAE

Barbarea australis J.D. Hook. $\dagger * 3$

Cardamine tenuifolia Hook.

Hymenolobus procumbens (L.) Nutt. ex Schinz. \& Thell. * 1

Lepidium pseudotasmanicum Thell. $\dagger$

Rorippa dictyosperma (Hook.) L. Johnson

BRUNONIACEAE

Brunonia australis Smith ex R. Br. $†$

CALLITRICHACEAE

Callitriche umbonata Hegelm. $\dagger$

CAMPANULACEAF

Isotoma fluviatilis (R. Br.) F. Muell. ex Benth. *

Lobelia alata Labill.

L. gibbosa Labill.

L. pratioides Benth. $† * 1,6$

L. rhombifolia deVriese $\dagger * 5$

Pratia pedunculata (R. Br.) Benth. $\dagger$

Wahlenbergia gracilenta $\mathrm{N}$. Lothian

W. gracilis (Forst. f.) Schrader

W. gymnoclada N. Lothian

W. multicaulis Benth.

W. stricta Sweet

\section{CARYOPHYLLACEAE}

Colobanthus apetalus (Labill.) Druce $* 8$

C. aff. strictus

Scleranthus biflorus (Forst. \& Forst. f.) Hook. f.

$S$. diander $\mathrm{R}$. Br. $\dagger$

Spergularia media (L.) Cyrillo

Stellaria flaccida Hook.

CASUARINACEAE

Allocasuarina littoralis (Salisb.) L. Johnson

A. verticillata (Lam.) L. Johnson

\section{CHENOPODIACEAE}

Chenopodium glaucum $\mathbf{L}$

C. pumilio $\mathrm{R}$. $\mathrm{Br}$. $+* 6$

Einadia nutans (R. Br.) A.J. Scott

\section{CLUSIACEAE}

Hypericum gramineum Forst. f.

$H$. japonicum Thunb.

CONVOLVULACEAE

Convolvulus erubescens Sims

Dichondra repens Forst. \& Forst. f.

Wilsonia rotundifolia Hook. $\dagger$

CRASSULACEAE

Crassula helmsii (Kirk) Cockayne

C. peduncularis (SMith) Meigen * 6

C. sieberana (Schult. \& Schult. f.) Druce

\section{DILLENIACEAE}

Hibbertia hirsuta (Hook.) Benth.

$H$. prostrata Hook

H. riparia (R. Br. ex DC.) Hoogl.

$H$. serpylififolia $\mathrm{R}$. Br. ex DC.

DROSERACEAE

Drossera peltata Thunb.

ssp. auriculata (Backh. ex Planchon) Conn ssp. peltata

D. pygmaea DC.

ELATINACEAE

Elatine gratioloides A. Cunn.

\section{EPACRIDACEAE}

Acrotriche serrulata (Labill.) R. Br.

Astroloma humifusum (Cav.) R. Br.

Brachyloma ciliatum (R. Br.) Benth.

Cyathodes parvifolia

Epacris excerta $\mathrm{R}$. Br. $\dagger$

E. impressa Labill.

Leucopogon collinus (Labill.) R. Br.

L. virgatus (Labill.) $\mathrm{R}$. Br.

Lissanthe strigosa (Sm.) R. Br.

Styphelia adscendens $\mathrm{R}$. Br.

EUPHORBIACEAE

Amperea xiphoclada (Sieber ex Spreng.) Druce Bertya rosmarinifolia Planch. $\dagger * 1,2$

Beyeria viscosa (Labill.) Miq.

Micrantheum hexandrum Hook. f. $\dagger$

Phyllanthus australis Hook. $\mathrm{f}$.

Poranthera microphylla Brongn.

\section{FABACEAE}

Acacia axillaris Benth. $\dagger$

A. dealbata Link

A. genistifolia Link

A. gunnii Benth.

A. mearnsi De Wild

A. melanoxylon $\mathrm{R}$. Br.

A. mucronata Willd. ex Wendl.

A. siculiformis A. Cunn. ex Benth. * 1

A. verticillata (L'Herit.) Willd. 
Aotus ericoides (Vent.) G. Don

Bossiaea cinerea $\mathrm{R}$. Br.

$B$. prostrata $\mathrm{R}$. Br.

$B$. riparia A. Cunn. ex Benth.

Daviesia latifolia $\mathrm{R}$. Br.

D. ulicifolia Andr.

Desmodium varians var. gunnii (Hook. f.) Benth. $\dagger$ * 6

Dillwynia cinerascens $\mathrm{R}$. Br.

Glycine latrobeana (Meissn.) Benth. =

Gompholobium huegelii Benth.

Hovea lanceolata Sims

$H$. linearis (Smith) $\mathrm{R}$. Br.

Indigofera australis Willd.

Kennedia prostrata $\mathrm{R}$. Br.

Platylobium obtusangulum Hook.

Pultenaea fasciculata Benth.

$P$. humilis Benth. ex Hook. f. $\dagger$

$P$. juniperina Labill.

$P$. prostrata Benth. ex Hook. f. $\dagger$

GENTIANACEAE

Sebaea ovata (Labill.) R. Br.

GERANIACEAE

Geranium sessiliflorum Cav.

ssp. brevicaule (Hook. f.) R.C. Carolin

$G$. solanderi R.C. Carolin

Pelargonium australe Willd.

GOODENEACEAE

Goodenia amplexans F. Muell. $+* 2,8$

G. elongata Labill.

G. humilis $\mathrm{R}$. $\mathrm{Br}$

G. lanata $\mathrm{R}$. Br.

G. ovata $\mathrm{Sm}$.

Selliera radicans Cav.

Velleia paradoxa $\mathrm{R}$. Br. +

HALORAGACEAE

Gonocarpus micranthus Thunb.

G. tetragynus Labill.

Haloragis aspera Lindley †

Myriophyllum glomeratum Schindler $+* 8$

$M$. integrifolium (Hook, f.) Hook. f.

$M$. pedunculatum Hook, f.

M. salsugineum Orch.

$M$. simulans Orch.

M. variifolium Hook. $\mathrm{f}$.

LAMIACEAE

Ajuga australis R. Br.

Mentha diemenica Spreng.

Prostanthera cuneata Benth. *2,6,7

$P$. rotundifolia $\mathrm{R}$. $\mathrm{Br}$.

Prunella vulgaris $\mathrm{L}$.

Teucrium corymbosum $\mathrm{R}$. Br.

Westringia rubiaefolia $\mathrm{R}$. Br.

LENTIBULARIACEAE

Utricularia australis $\mathrm{R} . \mathrm{Br} .{ }^{*} 1$
U. dichotoma Labill.

U. monanthos Hook. f.

LAURACEAE

Cassytha pubescens $\mathrm{R}$. $\mathrm{Br}$.

LINACEAE

Linum marginale A. Cunn. ex Planchon

LYTHRACEAE

Lythrum hyssopifolia $\mathrm{L}$.

MALVACEAE

Asterotrichion discolor (Hook.) Melville

Lawrencia spicata Hook.

MENYANTHACEAE

Villarsia reniformis $\mathrm{R}$. Br.

MYRTACEAE

Baeckea ramosissima A. Cunn.

Callistemon pallidus (Bonpl.) DC.

C. viridiflorus (Sims) Sweet

Calytrix tetragona Labill.

Eucalyptus amygdalina Labill.

E. obliqua Labill

E. ovata Labill.

E. pauciflora Sieber ex Spreng.

E. rodwayi R.T. Bak. \& H.T. Smith

E. rubida $\mathrm{H}$. Deane \& Maiden $\dagger$

E. viminalis Labill.

Leptospermum lanigerum (Ait.) $\mathrm{Sm}$.

L. scoparium Forst. \& Forst. f.

Melaleuca ericifolia $\mathrm{Sm}$.

M. gibbosa Labill.

OLEACEAE

Notelaea ligustrina Vent.

ONAGRACEAE

Epilobium billardierianum Ser. ex DC.

OXALIDACEAE

Oxalis perennans Haw.

PITTOSPORACEAE

Billardiera procumbens (Hook.) E. Bennett

$B$. scandens Sm.

Bursaria spinosa Cav.

Pittosporum bicolor Hook.

PLANTAGINACEAE

Plantago antarctica Dcne. $\dagger$

$P$. varia $\mathrm{R}$. Br.

POLYGALACEAE

Comesperma volubile Labill.

POLYGONACEAE

Muehlenbeckia axillaris (Hook. f.) Walp.

Persicaria hydropiper (L.) Opiz.

Polygonum decipiens R. Br. $+* 6$

Rumex brownii Campd.

R. dumosis A. Cunn. ex Meissn. $\dagger$

PORTULACACEAE

Montia australasica (Hook. f.) Pax \& Hoffm. PRIMULACEAE

Samolus repens (Forst. \& Forst. f.) Pers. 


\section{PROTEACEAE}

Banksia marginata Cav.

Grevillea australis R. Br.

Hakea lissosperma $\mathrm{R}$. $\mathrm{Br}$.

H. microcarpa $\mathrm{R}$. Br.

Lomatia tinctoria (Labill.) $\mathrm{R}$. $\mathrm{Br}$.

Persoonia juniperina Labill.

\section{RANUNCULACEAE}

Clematis aristata $\mathrm{R} . \mathrm{Br}$.

C. gentianoides DC.

C. microphylla DC.

Ranunculus decurvus (Hook. f.) Melville *6

$R$. glabrifolius Hook.

$R$. lappaceus $\mathrm{Sm}$.

R. pimpinellifolius Hook. * 6

$R$. prasinus (Menadue \& Crowden) $\dagger$

$R$. trichophyllus Chaix

\section{RHAMNACEAE}

Cryptandra amara $\mathrm{Sm}$. †

Discaria pubescens (Brongn.) Druce $\dagger * 6$

Pomaderris elliptica sens. Ewart

Spyridium ulicinum (Hook.) Benth.

S. vexilliferum (Hook.) Reiss.

Stenanthemum pimeleoides (Hook. f.) Benth.

ROSACEAE

Acaena agnipila Gand.

var. tenuiscarpa (Bitt.) Orch. †

A. echinata Nees

A. novae-zelandiae Kirk

A. ovina A. Cunn.

Rubus parvifolius $\mathrm{L}$.

\section{RUBIACEAE}

Asperula conferta Hook. f.

A. scoparia Hook. f. $\dagger * 6$

A. subsimplex Hook. f. $\dagger * 6$

Coprosma quadrifida (Labill.) Robinson

Galium australe DC.

G. ciliare Hook. f

$G$. gaudichaudii DC.

Opercularia ovata Hook. f.

O. varia Hook. f.

\section{RUTACEAF}

Eriostemon verrucosus A. Rich.
Phebalium squameum (Labill.) Engl. ssp. retusum (Hook.) P.G. Wilson †

SANTALACEAE

Exocarpos curpessiformis Labill.

E. strictus R. Br.

Leptomeria drupacea (Labill.) Druce

SAPINDACEAE

Dodonaea filiformis Link

D. viscosa (L.) N.J. Jacq.

SCROPHULARIACEAE

Euphrasia scabra $\mathrm{R}$. Br. $+* 5$

Glossostigma elantinoides (Benth.) ex Hook. f. * 2

Gratiola latifolia $\mathrm{R}$. Br. * 6

$G$. nana Benth.

Limosella australis $\mathrm{R}$. Br.

Mazus pumilio $\mathrm{R}$. Br.

Mimulus repens $\mathrm{R}$. Br.

Parahebe derwentiana (Andrews) B. Briggs \& Ehrend. $\dagger * 6$

Veronica calycina $\mathrm{R}$. Br.

V. formosa $\mathrm{R}$. Br.

V. gracilis R. Br.

V. scutellata L. $\dagger$

SOLANACEAE

Solanum nigrum L.

\section{STACKHOUSIACEAE}

Stackhousia gunnii Hook. f. †

S. monogyna Labill.

\section{STYLIDIACEAE}

Stylidium graminifolium Rich.

\section{THYMELEACEAE}

Pimelea curviflora $\mathrm{R} . \mathrm{Br}$.

$P$. glauca $\mathrm{R}$. Br.

$P$. humilis $\mathrm{R}$. Br

$P$. nivea Labill.

$P$. pauciflora $\mathrm{R}$. Br. $\dagger$

TREMANDRACEAE

Tetratheca pilosa Labill. * 6

$T$. procumbens Gunn ex Hook. f.

VIOLACEAE

Hymenanthera dentata R. Br. ex DC.

Viola betonicifolia $\mathrm{Sm}$.

$V$. hederacea Labill. 